\title{
Effect of keeping temperature on organoleptic quality of curd
}

\section{Mahendra Rai, R.K. Mehta and R.B. Gautam*}

N.D. University of Agriculture and Technology, Kumarganj, Faizabad (UP)

*Email: rksh_gautam@yahoo.co.in

\begin{abstract}
Keeping temperature plays an important role in making quality curds. Temperatures above optimum, adversely affect the organoleptic parameters of the curds. This experiment was conducted to the nature and magnitude of organoleptic parameters of soy-milk curd and buffalo milk curd at different keeping temperatures. Above optimum temperature of $25^{\circ} \mathrm{C}$, all the quality parameters of the different curds indicated gradual decrease in values till $35^{\circ} \mathrm{C}$ and quality loss increased faster then after except acidity. Acidity scores decreased from optimum temperature to $35^{\circ} \mathrm{C}$ and it again increased till $45^{\circ} \mathrm{C}$.
\end{abstract}

Keywords: Organoleptic, curds, quality, optimum temperature, Buffalo milk, Soy milk.

Paper cited: Rai, M., Mehta, R.K. and Gautam, R.B. (2018). Effect of keeping temperature on organoleptic quality of curd. South Asian Journal of Food Technology and Environment, 4(1): 616621.

\section{Introduction}

Milk has always been considered as an ideal food for infants and children and a good supplementary food for adults. Fresh milk has a slightly sweetish odour and flavour, is white or yellowish white in colour and has a sour odour (flavour). The keeping quality of milk is poor and as such its economic disposal expressed difficulties. Surplus milk is usually utilized as milk product which required be storing over longer periods and transporting to distant places for sale. Milk and milk products are important human diet. These are palatable, easy to digest and highly nutritious. Such a valuable food is available at 178 grams in 1991-92/person/day. In our country, this is against 283 grams/person/day as recommended by Indian council of medical research (ICMR). It is, therefore, necessary to conserve all the milk produced and also to find out an alternate source of milk to provide each individual of the country with the required and recommended dose of milk. This way the introduction of soybean for milk production came into picture in early seventies.
Soybean is very rich in protein and fat contents with the availability levels of 40 and 20 per cent respectively. The major drawback with the soybean is that it is very hard and contains anti nutritional factors. These anti nutritional factors are trypsin inhibitors. Trypsin is the main enzyme responsible for the digestion of protein. If not carefully handled, the soy-milk develops beany flavour during processing. Dahi is one of the most important widely popular indigenous fermented milk products in our country. In India 9.1 per cent of the total annual milk production is utilized for Dahi making. But no efforts have yet been made to produce it on commercial level.

Several Parameters such as varieties quality, chemical composition, flavour, taste, acidity, appearance, hardness etc of curd of Buffalo milk were studied by Bhattacharya, (1967); Chatterjee and Acharya (1992); Chauhan (1998); Deeth and Tamine (1961); Heinemann (1957); Humphreys and Plunkelt (1969); Khambatta and Dastur (1950); and Rangappa and Acharya (1965) reported it organoleptic results. Curd is the product made 
from pasteurized or boiled milk by souring natural or otherwise by a harmless lactic acid or other bacterial culture. It will be either plain or flavoured. Dahi should have 0.6 to 0.8 per cent acidity. Therapeutic uses of Dahi plays an important role in treatment of virginal discharge, cure of osteoporosis (calcium deficiency) and bone deformation in middle age women during and after menopause. Physicians in many countries have prescribed fermented milk for curing disorders of the stomach, intestine, liver, and also for stimulation of the appetite. The present problem was taken with the following objectives:

1. Treatment of soybean seed for milk extraction.

2. Preparation of curd from soy-milk and buffalo milk at different temperatures.

3. Comparison of soy-milk cud and buffalo milk curd as regards organoleptic qualities.

4. Standardization of temperature for quality curd preparation.

\section{Materials and Methods}

The study was conducted to know the variations in organoleptic qualities [odour (flavour), taste, acidity, appearance and hardness] of soy-milk curd and buffalo milk curd prepared at different temperature $\left(25^{\circ} \mathrm{C}\right.$, $35^{\circ} \mathrm{C}$, and $45^{\circ} \mathrm{C}$ ) and also to optimize the temperature for quality curd making.

This section deals with the details of experimental material, methods and technical programme related to the physical and sensory parameters (organoleptic quality) employed during the present investigation.
Preparation of curd: :Soy-milk and buffalomilk (one litre each) were taken separately in two steel bowls and heated for nearly 10 minutes till boiling on a gas stove. Heated milk was allowed to cool to body temperature. Six earthen bowls ( 3 for each category milk) were taken and filled with $150 \mathrm{ml}$ of milk (3 with soy-milk and 3 with buffalo-milk) with the help of measuring cylinder. Half teaspoon starter was mixed in each bowl and stirred with glass rod. Two bowls (one of soy-milk and other of buffalo-milk) were put in the oven and set at $25^{\circ} \mathrm{c}$ temperature. After nearly eight hours, the bowls were taken out from the oven. This way three set of curd were prepared at temperature level of $25^{\circ} \mathrm{C}, 35^{\circ} \mathrm{C}$, $45^{\circ} \mathrm{C}$ and their organoleptic qualities were assessed.

Extraction of milk from soy-bean: Extraction of milk from soybean seed was done on the basis of process flow given below in Fig.1. In general, $1 \mathrm{~kg}$ soybean seed yields $8 \mathrm{~kg}$ soy-milk.

Determination of organoleptic quality of curd: This is sensory evaluation related with sight, touch, smell and general appearance. The organoleptic qualities of curd were judged by a panel of 5 judges (Three panellists from food technology department and two from college of Home Science of NDUAT, Kumarganj, Faizabad ) on the basis of 100 point scale as given by Singh Tyagi (1975) (Table 1). The average value of quality scores of organoleptic tests as given by expert panel, have been put in observation Table 2 .

\section{Table 1: Scale curd of dahi}

\begin{tabular}{|c|l|l|}
\hline S. No. & Attributes & Perfect Score \\
\hline 1 & Odour (flavour) & 45 \\
\hline 2 & Taste & 30 \\
\hline 3 & Acidity & 10 \\
\hline 4 & Appearance & 10 \\
\hline 5 & Hardness & 05 \\
\hline & Total & 100 \\
\hline
\end{tabular}




\section{Process flow chart for making soy-milk}

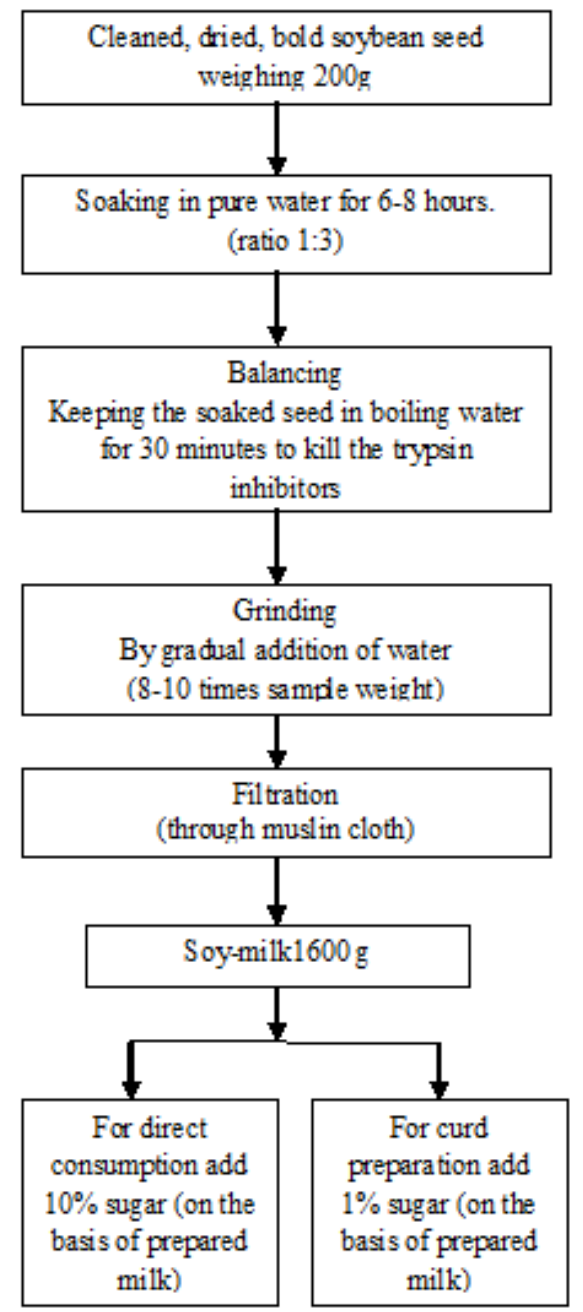

\section{Result and discussion}

Quality of Dahi is governed by selection of milk, standardization, heat treatment, homogenization, temperature and storage. Dahi is usually held for a long time and hence it undergoes spoilage by the action of yeasts and moulds. The quality of curd prepared by the different types of milk varies widely depending upon the type of milk used, quality of milk, method of preparation, heat treatment, duration and method of storage etc. In the present investigation an attempt has been made to ascertain the effect of different type of milk and heat treatment at different temperature levels on the quality of curd. For assessing the quality of curd, organoleptic method with the following factors, was taken into account:

Flavour score: The flavour score of curd varied widely with temperature and type of milk used. In both the cases, decreasing scores were observed with increased in temperature above $25^{\circ} \mathrm{C}$. At $25^{\circ} \mathrm{C}$ keeping temperature, flavour scores were 36 and 31 respectively for buffalo milk curd and soy-milk curd out of 45 marks allotted for the attributes whereas at $45^{\circ} \mathrm{C}$ the score were in order of 30 and 25 (Table 2 and Fig. 2\&3).

Fig.l Process flow chart for making soy-milk

Table 2: Organoleptic Quality Scores of cured of milk

\begin{tabular}{|c|c|c|c|c|c|c|c|c|}
\hline \multirow{3}{*}{ 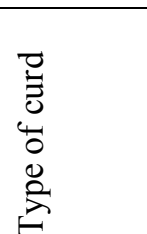 } & \multirow[b]{3}{*}{$\frac{\dot{0}}{z}$} & \multirow{3}{*}{ 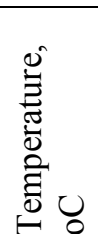 } & \multicolumn{4}{|c|}{ Organoleptic quality of curd } & \multirow[b]{2}{*}{ hardness } & \multirow[t]{2}{*}{ Total } \\
\hline & & & odour & taste & acidity & appearance & & \\
\hline & & & 45 & 30 & 10 & 10 & 05 & 100 \\
\hline \multirow{3}{*}{$\begin{array}{l}\text { Buffalo } \\
\text { milk } \\
\text { Curd }\end{array}$} & 1 & 25 & 36 & 28 & 8 & 8 & 5 & 85 \\
\hline & 2 & 35 & 34 & 25 & 7 & 8 & 4.5 & \\
\hline & 3 & 45 & 30 & 20 & 7.5 & 7.5 & 4 & 69 \\
\hline \multirow{3}{*}{$\begin{array}{l}\text { Soy-milk } \\
\text { curd }\end{array}$} & 4 & 25 & 31 & 25 & 7 & 6 & 5 & 74 \\
\hline & 5 & 35 & 28 & 22 & 6 & 6 & 4.5 & 66.5 \\
\hline & 6 & 45 & 25 & 18 & 6.5 & 5.5 & 4 & 59 \\
\hline
\end{tabular}


Mahendra Rai, R.K. Mehta and R.B. Gautam

$\square$ Odour $\square$ Taste $\square$ Acidity $\square$ Appearance $\square$ Hardness

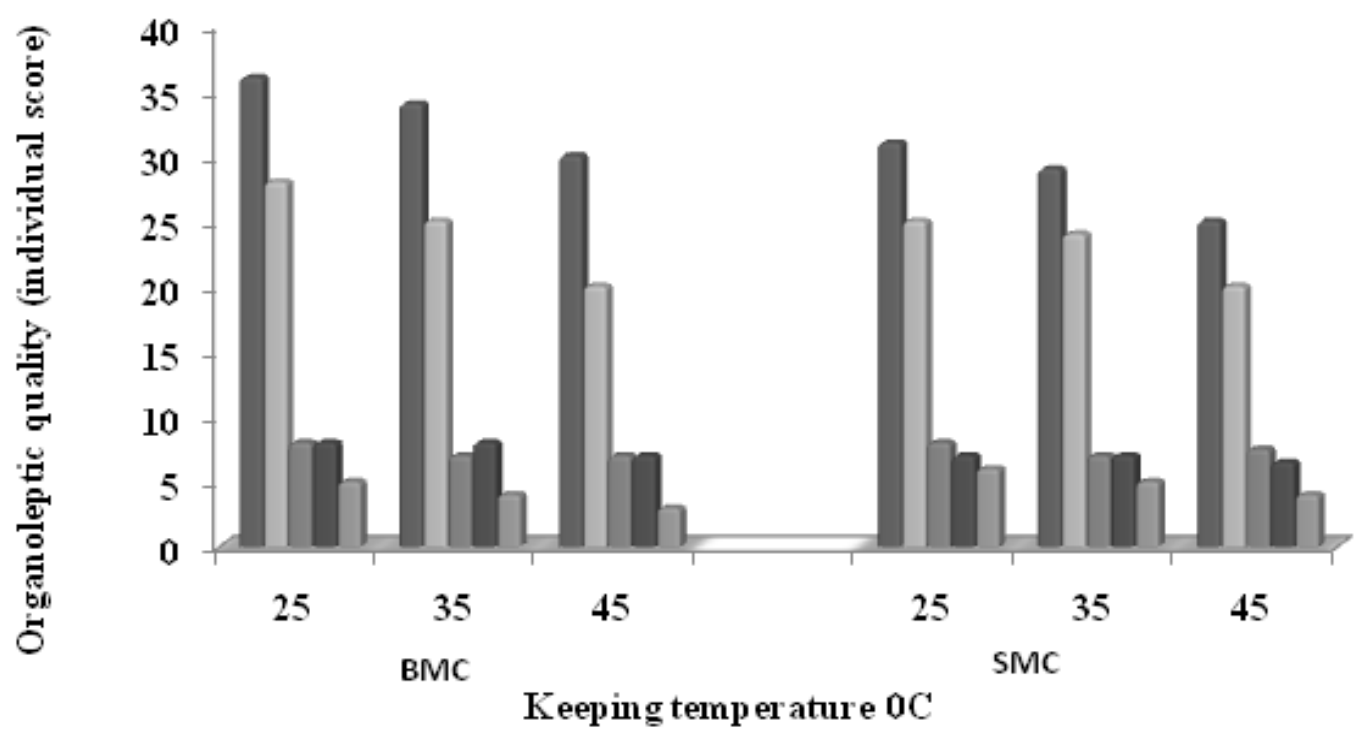

Fig.2: Effect of temper ature on or ganoleptic quality (cummulative) of BMC and SMC

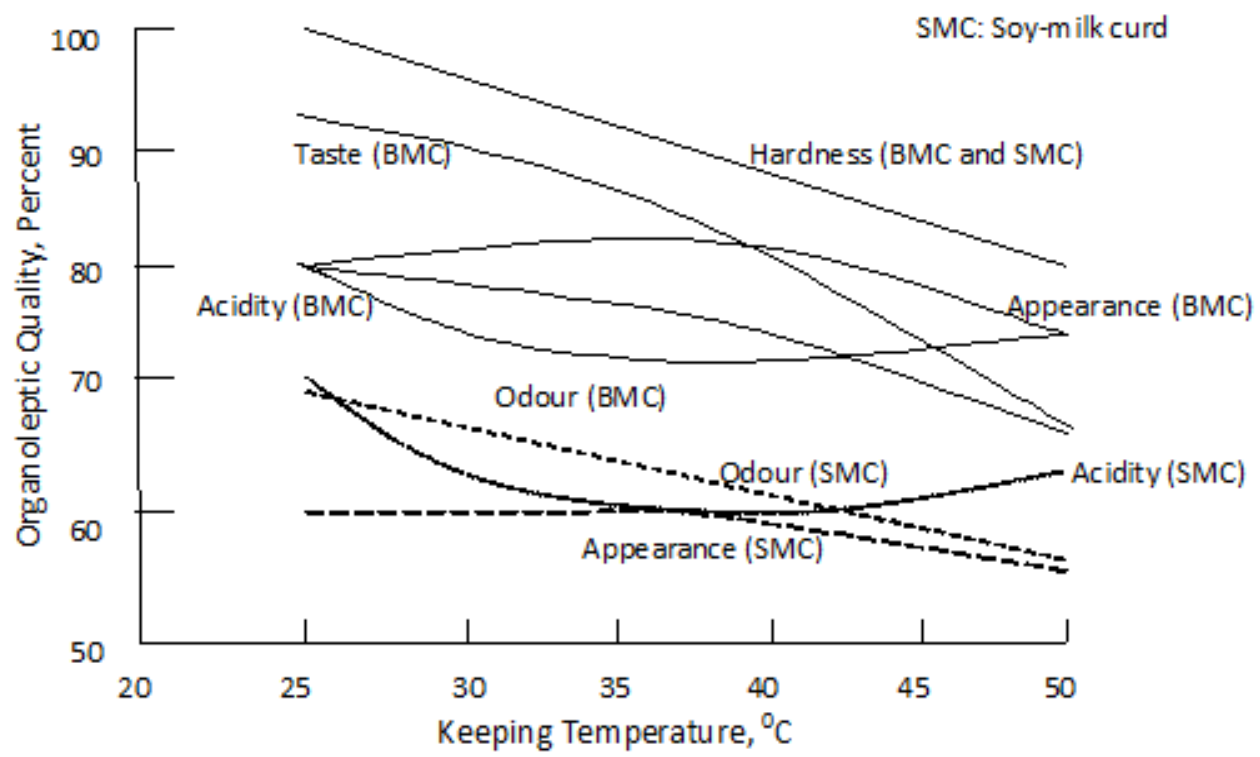

Fig: 3. Effect of Tempera ture on Organoleptic Quality (Individual) of BMC \& SMC 
Taste: Taste score of B.M.C. (buffalo milk curd) was 28 at $25^{\circ} \mathrm{C}$ keeping temperature whereas the same score for S.M.C. (soy-milk curd) was 25 out of 30 . With rise in keeping temperature above optimum, there was decrease in taste in both the cases (Fig. 2-5).
Acidity: With increase in keeping temperature, there was decrease in acidity scores up to $35^{\circ} \mathrm{c}$ and then after it decrease again in both cases (Fig.2-5).

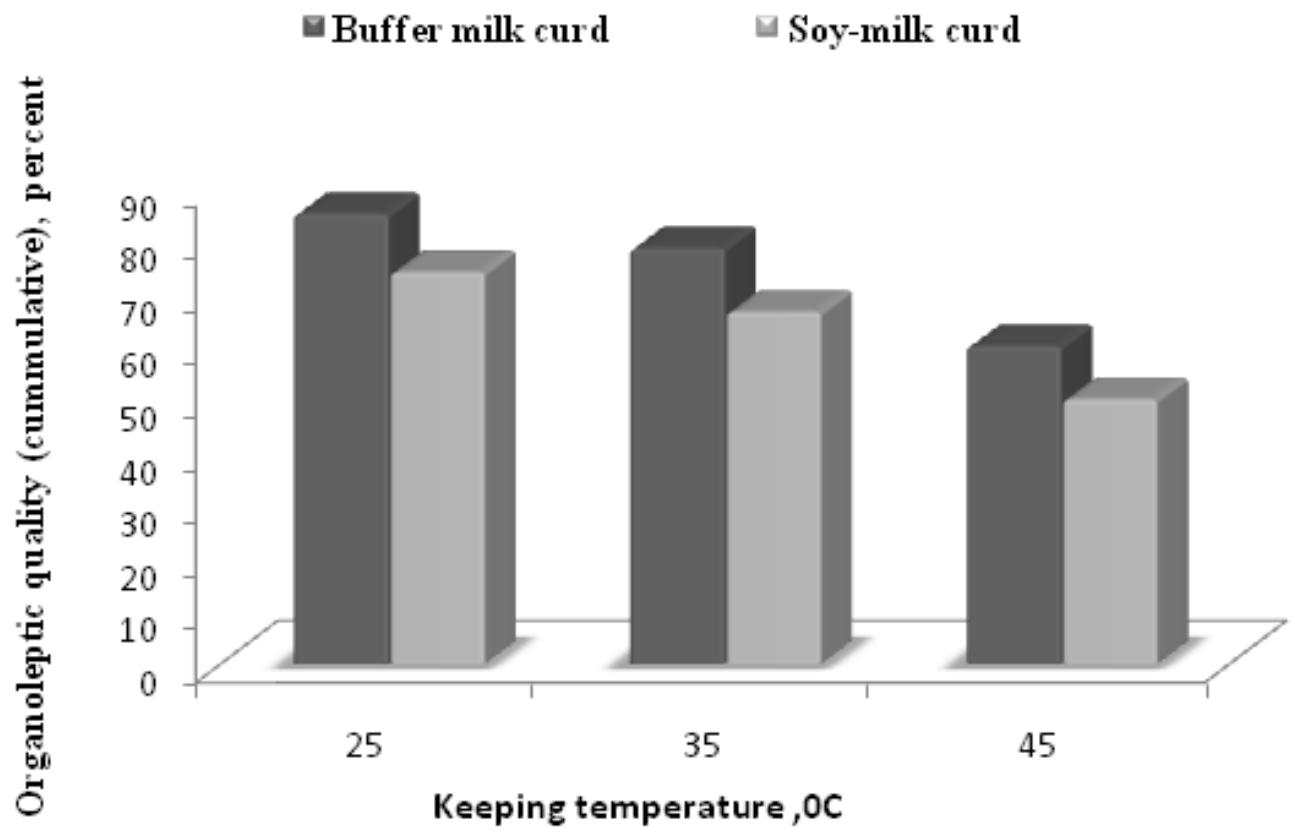

Fig.4: Effect of temper ature on organoleptic quality (cummulative) of $\mathrm{BMC}$ and SMC

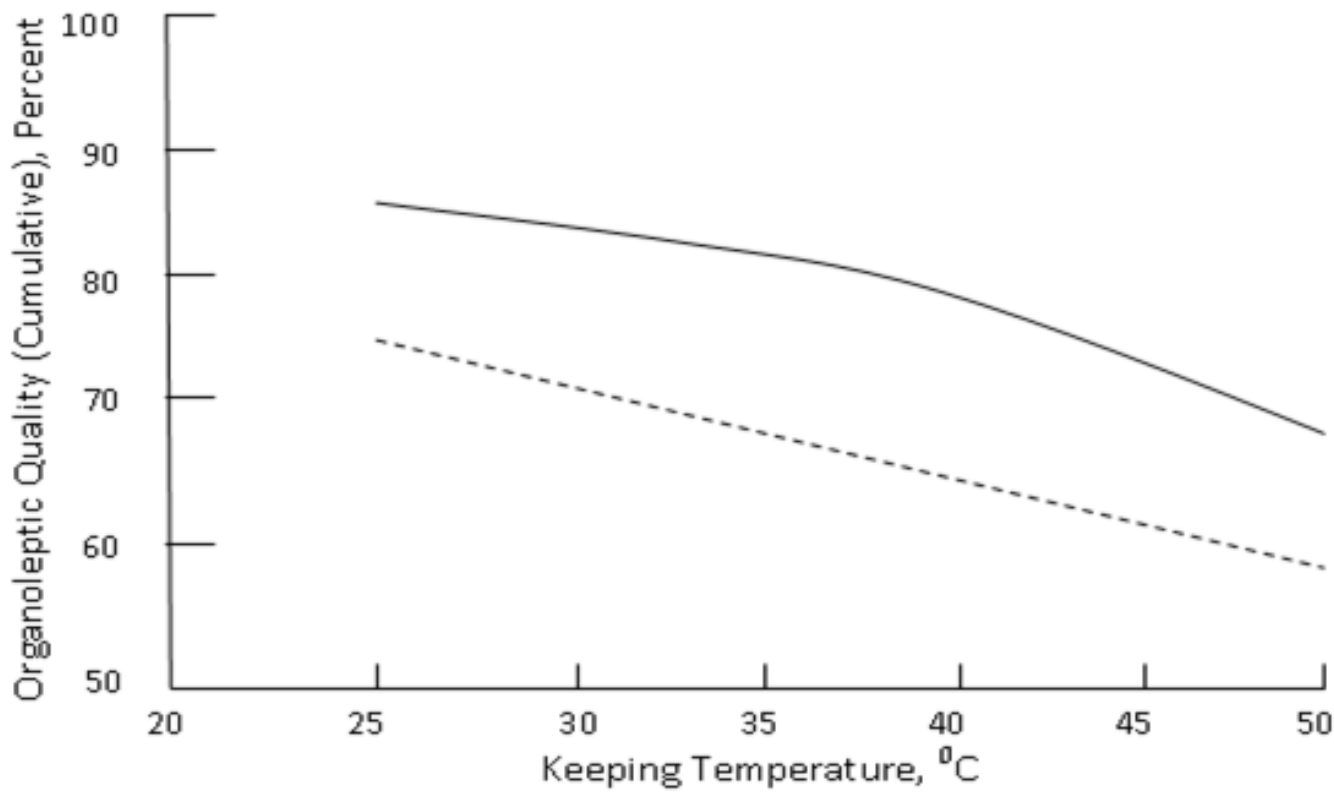

Fig: 5. Effect of Temperature on Organolep tic Quality (Cumulative) of BMC \& SMC 
Appearance: No significant difference was observed in appearance in both the cases due to increase in keeping temperature. However, at $45^{\circ} \mathrm{c}$ keeping temperature, slight decrease in appearance was observed (Fig. 2-5).

Hardness: Hardness scores for all types of curds were similar. However, after $25^{\circ} \mathrm{c}$ keeping temperature, decrease in hardness was observed in both the cases (Fig. 2-5).

\section{Conclusion}

Through soy-milk resembles nearly all the constituents of natural milk, it cannot reach the quality level of cow or buffalo milk or its products. Soy-milk curd produces beany flavour. Optimum keeping temperature of milk (all types) for quality curd making is $25^{\circ} \mathrm{C}$. Quality score (cumulative) for buffalo milk curd at optimum keeping temperature of $25^{\circ} \mathrm{C}$ is found to be 85 per cent whereas the same value for soy-milk curd is 74 per cent. With increase in keeping temperature above $25^{\circ} \mathrm{C}$, the acidity decrease and after $40^{\circ} \mathrm{C}$ keeping temperature, it again starts increasing in both the cases and hence, acidity scores indicate decreasing trend till $40^{\circ} \mathrm{C}$ and it increases then after. Quality scores (cumulative) for buffalo milk curd and soy milk curd at $45^{\circ} \mathrm{C}$ keeping temperature are found to be at minimum level of 69 per cent and 59 per cent respectively. All the parameters of organoleptic quality of curd (except acidity) indicate gradual decrease in value above $25^{\circ} \mathrm{C}$ till $35^{\circ} \mathrm{C}$ and then after, quality loss is bit faster.

\section{References}

1. Bhattacharya, D.C. (1967). New varieties of dahi (fermented whole milk). Indian Dairyman, 19:35-38.

2. Chatterjee, A.K. and Acharya, R.M. (1992). Heading for $21^{\text {st }}$ century Dairy India. In Gupta, R.P., ed., Dairy India $19924^{\text {th }}$ Edition, Delhi. 17.

3. Chauhan, S. (1998). Effect of different types of milk on quality of curd. M.Sc. (home science) Thesis. C.S.A. University, Kanpur.

4. Deeth, H.C. and Tamine, A.T. (1961). Yoghurt, Nutritive and therapeutic aspects. Journal of Food Protection, 44:78-86.

5. Heinemann, B. (1957). Influence of cottage cheese starter organisms on strength of curd at the time of cutting. Journal of Dairy Science, 40:437-38.

6. Humphreys, C.I. and Plunkelt, M. (1969). A review of dahi and its manufacture. Dairy Science Abstract, 31(11): 602-22.

7. Khambatta, J.S. and Dastur, N.M. (1950). Studies on the changes in chemical composition of milk during souring. Indian Journal of Dairy Science, 3:147.

8. Rangappa, K.S. and Acharya, R.M. (1965). Dahikusum or Indian ice cream. Indian Dairyman, 17:13-15.

$\begin{array}{ll}\text { Received } & : \text { Jan, 2018 } \\ \text { Revised } & \text { : April., 2018 } \\ \text { Published } & \text { : June, 2018 }\end{array}$

